\title{
THE MOBILITY OF APPALACHIAN AMERICANS
}

Lowell Gallaway, Charles McBride, and Richard Vedder

Ohio University*

Perhaps no region of the United States has ever experienced out-migration of the magnitude observed in the Appalachian region of the United States since 1940. As Table 1 indicates, negative net migration (in-migration minus out-migration) over a ten year period has in several instances exceeded 20 percent of the initial population of the Appalachian portion of the state. This paper will analys is this out-migration, utilizing contemporary statistical estimation techniques in order to provide answers to the following questions: Is the behavior of the Appalachian migrant consistent with the expectations of conventional economic theory? Has the Appalachian migrant been less responsive to the sources of economic abundance than his non-Appalachian counterpart? Has his fondness or affinity for the Appalachian region played a major role in his movement decisions? Still other questions arise. Have Appalachian migrants become more responsive to economic considerations over time? Most important, perhaps, have Appalachian Americans improved their relative and/or absolute economic status by moving? ${ }^{2}$

Implicit (and sometimes quite explicit) in much of the rising concern about Appalachia in the 1960's was a sense that this region of the United States has stagnated economically because of cultural factors stemming from the relative geographic isolation of much of the region. The impression was sometimes given that Appalachians were somehow different, backward, and/ or uninterested in economicopportunities. In this connection, it is interesting to note that the title of one widely read work on the Appalachian culture is Yesterday's People. ${ }^{3}$ We hope that this examination of the location decisions of Appalachian migrants might provide some evidence relating to the validity of these assertions.

Table I. Magnitude of Out-Migration from Appalachia

\begin{tabular}{lcccc} 
State & $\begin{array}{c}\text { Appalachian } \\
\text { Population, 1960 }\end{array}$ & $\begin{array}{c}\text { Change in Population } \\
1950-1960\end{array}$ & $\begin{array}{c}\text { Net Migration Rate } \\
1950-1960\end{array}$ \\
\cline { 2 - 3 } Alabama & $1,982,286$ & $6.5 \%$ & $-11.1 \%$ \\
Georgia & 575,024 & & 8.9 & -10.6 \\
Kentucky & 922,152 & & -14.0 & -31.8 \\
Maryland & 195,808 & & 3.2 & -7.8 \\
Mississippi & 406,187 & & -4.7 & -21.2 \\
New York & $1,000,064$ & 9.0 & -3.8 \\
North Carolina & 939,340 & 6.6 & -9.6 \\
Ohio & $1,119,555$ & 8.2 & -4.5 \\
Pennsylvania & $5,930,784$ & 2.5 & -9.3 \\
South Carolina & 586,523 & 12.1 & -7.8 \\
Tennessee & $1,607,689$ & & & -11.4 \\
Virginia & 500,334 & 5.1 & -22.4 \\
West Virginia & $1,860,421$ & -5.1 & -22.3
\end{tabular}

Source: U.S. Bureau of the Census, 1960 Census of Population.

* The authors are Professor of Economics, undergraduate student, Associate Professor of Economics, respectively, at Ohio University. All calculations were made at the Ohio University Computer Center. 
I.

Most of the recent theorizing about labor mobility has emphasized the importance of income levels and/or job opportunity considerations. In terms of our analysis, it is suggested that, ceteris paribus, greater numbers of Appalachian migrants will go to states with higher levels of wages orincome, and/or to states with more job opportunities. Ignoring the cost of movement, we would hypothesize that

$$
M_{i j}=f\left(Y_{j}, J_{j}\right), \underline{\partial M_{i j}}>0, \underline{ }, \underline{M_{i j}}
$$

where $M_{i j}$ denotes the flow of migrants from the $i$ th to the $j$ th state, $Y_{j}$ the level of income in the $j_{\text {th }}$ state, and $J_{j}$ the availability of jobs in that state.

Of course, the re are real costs associated with movement, and these costs presumably increase as the distance from $\underline{i}$ to $j$ increases. The cost associated with distance include not only the cost of t $\bar{r}$ ansportation, but also the cost of obtaining labor market information, and also certain nonpecuniary costs associated with the differences in physical and cultural climate that are likely to grow as the distance from $i$ to $j$ increases. At this point, we might note that at least one observer of Appalachianmigration, Edgar $M$. Hoover, argues that "distance... has not been a significant deterrent once the decision to move has been made. "4 Nonetheless, economic theory would suggest revising [1] to read

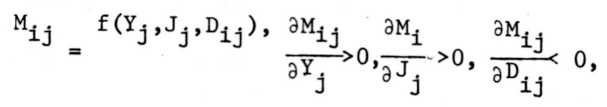

Where $D_{i j}$ is the distance from the $\underline{i t h}$ to the $\underline{j}$ th state.

Much of the geographic labor mobility in the United States has involved movement from relatively sparsely populated rural areas to relatively densely populated urban areas. We would suggest, however, that the farm-to-city movement has occurred not because of a particular fondness on the part of the migrants for city life, but because income levels and employment opportunities are greater in the urban areas. If everything else (including income levels and job opportunities) were held equal, we would not expectmigrants to flock to urban areas. Appalachia, in particular, is substantially more rural than most American regions, so one would expect, ceteris paribus, that Appalachian migrants might have some preference for relatively less densely populated surroundings. Therefore, we would hypothesize, ceteris paribus, that

$$
\frac{\partial M_{i j}}{\partial P_{j}}<0
$$

where $P_{j}$ is the density of population of the $j$ th state.

Finally, we have noted above that some observers have suggested that some sort of cultural, socioeconomic dualism exists: the people of Appalachia have different values and wants than persons living in the non-Appalachian parts of the United States. If this were so, one would expect that migrant Appalachians, ceteris paribus, would go to other a reas within this Appalachian subculture. Therefore, we would expect 


$$
\frac{\partial M_{i j}}{\partial A_{j}}>0,
$$

where $A_{j}$ is a measure of the extent that an area is Appalachian in character.

To summarize, we are hypothesizing that Appalachian migrants, ceteris paribus, are likely to go in greater numbers to areas with high incomes and greater job opportunities, to areas that are relatively sparsely populated, to a reas relatively close to their original home, and to areas which are relatively "Appalachian" in character. Symbolically,

$$
\begin{aligned}
& M_{i j}=f\left(Y_{j}, J_{j}, D_{i j}, P_{j}, A_{j}\right), \\
& \frac{\partial M_{i j}}{\partial Y_{j}}>0, \frac{\partial M_{i j}}{\partial J_{j}}>0, \frac{\partial M_{i j}}{\partial D_{i j}}<0, \frac{\partial M_{i j}}{\partial P_{j}}<0 \frac{\partial M_{i j}}{\partial A_{j}}>0,
\end{aligned}
$$

II.

For our basic source of migration data, we have used the 1955-1960 mobility statistics included in the 1960 Census. 5 Residents of the various states in 1960 are classified according to their residence in 1955. The data provide information not only on the interstate movement of migrants, but also information on movement between Census areas within states. In order to analyze Appalachian migration, we utilized the migration statistics for those Census areas corresponding with the Appalachian region as defined by the Appalachian Regional Commission. More specifically, we recorded the number of persons living in the Appalachian portion of the ith state in 1955 who moved by 1960 to each of the other 47 states or to anothe $\mathrm{r}$ Census area within the ith state itself.

For our income measure, we used standard state per-capita income estmates for 1960 compiled by the Department of Commerce. The measurement of job opportunities presents a problem. We chose to use Censes estimates of total employment by states for 1960. The reader should be forewarned immediately of the difficulties in interpreting this variable $\mathrm{J}$. First, it is a measure of the demand for labor, rather than a measure of the relationship between the demand and supply which is implied by the term "job opportunity." Second, the number of jobs in any state is highly correlated with population size. There is real doubt, then, whether our variable $\mathrm{J}$ is serving as a measure of job opportunity, as a population scaling measure, or, perhaps, both. It should be pointed out, however, that to the extent that $\mathrm{J}$ serves as a proxy for the population size of a state, that is not completely undesirable as some account should be made of population differences between the states before drawing inferences about the true relationships between the other independent variables (e.g. income and distance) and M. Also, the Jvariable as defined has been used in similar modelused to examine the migration of native Americans for the period since 1850.6 Our use of a similar job opportunity variable facilitates comparison with these historical results. Therefore, we proceed, with some caution, including $\mathrm{J}$ in our model.

Distance was measured simply by taking the number of statute miles from the leading population center of the ith state to the leading population 
center of the jth state. In some instances, particularly in predominantly agicultural states, the geographic center of the state was used. $P_{j}$ was simply defined as the 1960 population per square mile in the jth state. The degree to which a state is Appalachian in character was measured by taking the percent of the jth state's 1960 population living in an Appalachian region (for the 35 non-Appalachian states, this figure, of course, was zero).

The basic technique used to analyze the data is multiple linear regression analysis. Scatter diagrams indicated that the dependent and independent variables are related in a non-linear manner, and that a log-linear model would be most appropriate. An added advantage of the log-linear model is that it provides us with direct estimates of the elasticity of migration with respect to each of the independent variables.

Since one of our original questions related to the extent to which Appalachian and non-Appalachian migrants differed with respect to location decisions, we analyzed both the movement of Appalachians and migrants from the non-Appalachian parts of Appalachian state in terms of the model specified above.

III.

The empirical results a re reported in Tables II through VII. As the data in Table VII indicate, our model works quite well, explaining 70 to 80 percent of the variance in labor flows from both the Appalachian and the non-Appalachian portions of the 13 Appalachian states to the 48 geographically contiguous states in most instances. Turning first to the Appalachian migrants, in every instance the relationship between migration and each of the independent variables was in the direction posited in the theoretical discussion above.

Migrants seemed quite sensitive to income differentials, with the elasticity of migration with respect to changes in per capita income exceeding unity in 11 of 13 instances. 7 While in a number of cases the results we re not quite acceptable at standard levels of statistical reliability, in every instance the coefficient had the expected sign and in 11 of 13 cases it was greater than its standard error. Moreover, the results for the two states wheremigration was the largest, Pennsylvania and West Virginia, were statistically significant beyond the one percent level with elasticities of 2.5 and 2.4 respectively.

Table II. Elasticity of Migration with Respect to Per Capita Income ${ }^{a}$

\begin{tabular}{|c|c|c|}
\hline State & $\begin{array}{c}\text { Appalachian } \\
\text { Residents } \\
\end{array}$ & $\begin{array}{r}\text { Non-Appala } \\
\text { Reside } \\
\end{array}$ \\
\hline Alabama & $\begin{array}{c}1.14029 \\
(0.91572)\end{array}$ & $\begin{array}{c}0.73057 \\
(0.91028)\end{array}$ \\
\hline Georgia & $\begin{array}{c}1.68741^{\mathrm{b}} \\
(1.07404)\end{array}$ & $\begin{array}{r}1.77186^{b} \\
(0.77884)\end{array}$ \\
\hline Kentucky & $\begin{array}{c}1.35397 \\
(1.05749)\end{array}$ & $\begin{array}{c}0.78797 \\
(1.04491)\end{array}$ \\
\hline Maryland & $\begin{array}{c}2.04845^{b} \\
(1.34321)\end{array}$ & $\begin{array}{r}1.36220^{\mathrm{b}} \\
(0.74413)\end{array}$ \\
\hline Mississippi & $\begin{array}{c}1.60826^{b} \\
(1.19364)\end{array}$ & $\begin{array}{r}1.25739^{\mathrm{b}} \\
(0.92890)\end{array}$ \\
\hline
\end{tabular}


Table II. Elasticity of Migration with Respect to Per Capita Incomea Continued

\begin{tabular}{|c|c|c|}
\hline State & $\begin{array}{r}\text { Appalachian } \\
\text { Residents } \\
\end{array}$ & $\begin{array}{c}\text { Non-Appalachian } \\
\text { Residents }\end{array}$ \\
\hline New York & $\begin{array}{r}1.87686^{b} \\
(0.80177)\end{array}$ & $\begin{array}{r}1.57902^{b} \\
(0.79354)\end{array}$ \\
\hline North Carolina & $\begin{array}{c}0.48162 \\
(0.88631)\end{array}$ & $\begin{array}{c}0.39217 \\
(0.70827)\end{array}$ \\
\hline Ohio & $\begin{array}{l}1.60882^{b} \\
(0.77874)\end{array}$ & $\begin{array}{c}1.53292^{b} \\
(0.70428)\end{array}$ \\
\hline Pennsylvania & $\begin{array}{c}2.50161 \\
(0.76774)\end{array}$ & $\begin{array}{c}1.76540 \\
(0.73100)\end{array}$ \\
\hline South Carolina & $\begin{array}{c}1.18786 \\
(0.92354)\end{array}$ & $\begin{array}{c}1.40919^{b} \\
(0.78062)\end{array}$ \\
\hline Tennessee & $\begin{array}{c}9.73266 \\
(0.95022)\end{array}$ & $\begin{array}{l}-0.79348 \\
(0.87137)\end{array}$ \\
\hline $\begin{array}{l}\text { Virginia } \\
\text { West Virginia }\end{array}$ & $\begin{array}{c}1.13505 \\
(0.99581) \\
2.44666^{\mathrm{C}} \\
(0.88224)\end{array}$ & $\begin{array}{c}0.52418 \\
(0.60435)\end{array}$ \\
\hline $\begin{array}{l}\text { a Numbers in } \\
\text { b Statistically } \\
\text { c Statistically }\end{array}$ & $\begin{array}{l}\text { standard er } \\
\text { ten percen } \\
\text { one percen }\end{array}$ & \\
\hline
\end{tabular}

Table III. Elasticity of Migration with Respect to Job Opportunity ${ }^{a}, b$

\begin{tabular}{|c|c|c|}
\hline State & $\begin{array}{l}\text { Appalachian } \\
\text { Residents } \\
\end{array}$ & $\begin{array}{l}\text { Non-Appalachian } \\
\text { Residents }\end{array}$ \\
\hline Alabama & $\begin{array}{c}1.17870^{b} \\
(0.15219)\end{array}$ & $\begin{array}{c}1.05585^{b} \\
(0.15128)\end{array}$ \\
\hline Georgia & $\begin{array}{c}1.28145^{b} \\
(0.18319)\end{array}$ & $\begin{array}{r}0.82487^{b} \\
(0.13284)\end{array}$ \\
\hline Kentucky & $\begin{array}{r}0.98532^{b} \\
(0.20380)\end{array}$ & $\begin{array}{c}1.09051^{b} \\
(0.20137)\end{array}$ \\
\hline Maryland & $\begin{array}{c}0.77621^{b} \\
(0.30149)\end{array}$ & $\begin{array}{c}0.78046^{b} \\
(0.16702)\end{array}$ \\
\hline Mississippi & $\begin{array}{l}1.11484^{b} \\
(0.18303)\end{array}$ & $\begin{array}{l}1.22435^{b} \\
(0.14244)\end{array}$ \\
\hline New York & $\begin{array}{c}1.01212 b \\
(0.17984)\end{array}$ & $\begin{array}{r}0.83627^{b} \\
(0.17799)\end{array}$ \\
\hline North Carolina & $\begin{array}{r}1.03157^{\mathrm{b}} \\
(0.18049)\end{array}$ & $\begin{array}{r}1.05354^{\mathrm{b}} \\
(0.14424)\end{array}$ \\
\hline Ohio & $\begin{array}{r}1.00528^{b} \\
(0.15773)\end{array}$ & $\begin{array}{r}1.20421^{b} \\
(0.14264)\end{array}$ \\
\hline Pennsylvania & $\begin{array}{c}0.94173^{b} \\
(0.17012)\end{array}$ & $\begin{array}{c}1.76540 \mathrm{~b} \\
(0.73100)\end{array}$ \\
\hline South Carolina & $\begin{array}{l}1.15030^{b} \\
(0.16620)\end{array}$ & $\begin{array}{r}0.80140^{b} \\
(0.14048)\end{array}$ \\
\hline Tennessee & $\begin{array}{l}1.03723^{b} \\
(0.17069)\end{array}$ & $\begin{array}{l}1.12293^{b} \\
(0.24961)\end{array}$ \\
\hline Virginia & $\begin{array}{c}1.03825 \mathrm{~b} \\
(0.21891)\end{array}$ & $\begin{array}{r}0.88006^{b} \\
(0.13285)\end{array}$ \\
\hline West Virginia & $\begin{array}{c}0.92349 \mathrm{~b} \\
(0.18166)\end{array}$ & \\
\hline
\end{tabular}


Table III. Elasticity of Migration with Respect to Job Opportunity, ${ }^{a, b}$ Cont.

a Numbers in parentheses are standard errors.

b All elasticity coefficients shown are statistically significant at the one percent level or beyond.

Table IV. Elasticity of Migration with Respect to Distance ${ }^{a}$

\begin{tabular}{|c|c|c|}
\hline State & $\begin{array}{c}\text { Appalachian } \\
\text { Residents } \\
\end{array}$ & $\begin{array}{c}\text { Non-Appalachian } \\
\text { Residents } \\
\end{array}$ \\
\hline Alabama & $\begin{array}{r}-1.51013^{c} \\
(0.25498)\end{array}$ & $\begin{array}{r}-1.26436^{c} \\
(0.25347\end{array}$ \\
\hline Georgia & $\begin{array}{r}-1.70760 \\
(0.29373)\end{array}$ & $\begin{array}{r}-1.45029^{c} \\
(0.21300)\end{array}$ \\
\hline Kentucky & $\begin{array}{r}-1.14243^{c} \\
(0.29512)\end{array}$ & $\begin{array}{c}-0.98297 c \\
(0.29259\end{array}$ \\
\hline Maryland & $\begin{array}{r}-0.51605 \\
(0.39939)\end{array}$ & $\begin{array}{r}-0.54601^{b} \\
(0.32120)\end{array}$ \\
\hline Mississippi & $\begin{array}{c}-1.811613^{c} \\
(0.29542)\end{array}$ & $\begin{array}{r}-1.64464^{c} \\
(0.22990)\end{array}$ \\
\hline New York & $\begin{array}{r}-0.40830^{b} \\
(0.22156)\end{array}$ & $\begin{array}{r}-0.42868^{b} \\
(0.21929)\end{array}$ \\
\hline North Carolina & $\begin{array}{r}-0.94215^{c} \\
(0.28904)\end{array}$ & $\begin{array}{c}-1.211928^{c} \\
(0.23098)\end{array}$ \\
\hline Ohio & $\begin{array}{r}-0.60634^{c} \\
(0.19061)\end{array}$ & $\begin{array}{r}0.49058^{c} \\
(0.17238)\end{array}$ \\
\hline Pennsylvania & $\begin{array}{r}-0.32147 \mathrm{~b} \\
(0.20152)\end{array}$ & $\begin{array}{r}-0.57025^{c} \\
(0.19188)\end{array}$ \\
\hline South Carolina & $\begin{array}{r}-1.40694^{c} \\
(0.27890)\end{array}$ & $\begin{array}{r}-1.31316^{c} \\
(0.23574)\end{array}$ \\
\hline Tennessee & $\begin{array}{r}-0.92704^{c} \\
(0.27220)\end{array}$ & $\begin{array}{r}-1.12293^{c} \\
(0.24961)\end{array}$ \\
\hline Virginia & $-0.904009^{c}$ & $\begin{array}{r}-0.67132^{c} \\
(0.18389)\end{array}$ \\
\hline West Virginia & $\begin{array}{r}-1.00772^{c} \\
(0.31122)\end{array}$ & \\
\hline
\end{tabular}

a Numbers in parentheses are standard errors.

b Statistically significant at the ten percent level or beyond.

c Statistically significant at the one percent level or beyond.

Table V. Elasticity of Migration with Respect to Population Density ${ }^{\text {a }}$

\section{State}

Alabama

Georgia

Kentucky

Maryland

Mississippi
Appalachian Residents

$-0.17875^{b}$

(0.11863)

$-0.43199^{c}$

(0.15278)

$-0.22943^{\mathrm{b}}$

(0.16650)

- 0.14666

(0.31274)

$-0.30045^{\mathrm{b}}$

(0.13575)
Non-Appalachian Residents

$-0.24314^{b}$

(0.11793)

$-0.15461^{b}$

(0.11079)

$-0.26067 \mathrm{~b}$

(0.16452)

$-0.02639$

(0.17326)

$-0.42439^{c}$

(0.10564) 
Table V. Elasticity of Migration with Respect to Population Density ${ }^{\text {a }}$ Cont.

\begin{tabular}{lc} 
& $\begin{array}{c}\text { Appalachian } \\
\text { State }\end{array}$ \\
\cline { 2 - 2 } New York & -0.12646 \\
& $(0.19890)$ \\
North Ca rolina & $0.27003 \mathrm{~b}$ \\
& $(0.17524)$ \\
Ohio & $-0.35116^{\mathrm{C}}$ \\
& $(0.13752)$ \\
Pennsylvania & -0.05981 \\
& $(0.17762)$ \\
South Ca rolina & -0.44390 \\
& $(0.14988)$ \\
Tennessee & -0.15748 \\
Virginia & $(0.13535)$ \\
West Virginia & 0.32666 \\
& $(0.21467$ \\
& -0.26098 \\
& $(0.17211)$
\end{tabular}

Non-Appalachian Residents

$-0.06140$

$(0.19086)$

$-0.24106^{b}$

(0.14004)

$-0.25163^{b}$

(0.12437)

0.01879

$((0.16912)$

- 0.07894

(0.12669)

$-0.30003^{c}$

(0.12412)

$-0.08984$

(0.13029)

a Numbers in parentheses are standard errors.

b Statistically significant at the ten percent level or beyond.

c Statistically significant at the one percent level or beyond.

Table VI. Elasticity of Migration with Respect to Affinity for Appalachia ${ }^{a}$

\section{$\underline{\text { State }}$}

Alabama

Georgia

Kentucky

Maryland

Mississippi

New York

North Carolina

Ohio

Pennsylvania

South Carolina

Tennessee

Virginia

West Virginia
Appalachian

Residents

0.01482

(0.1819)

0.06811

(0.13531)

$0.26003^{b}$

$(0.14956)$

$0.54684^{c}$

$(0.21158)$

0.07229

$(0.12370)$
0.12785
(0.1176)
0.17707
$(0.140261)$
$0.44647^{c}$
(0.15927)
$0.34147^{\mathrm{c}}$
(0.11083)
0.04127
(0.12738)

Non-Appalachian

Residents
0.01362
$(0.10754)$
$-0.02879$
(0.09812)
0.14223
(0.14778)
$0.19448^{\mathrm{b}}$
(0.11721)
$-0.03461$
$(0.09627)$

0.02496

(0.11063)

0.03460

(0.11209)

$0.22379 \mathrm{~b}$

$(0.10210)$

$0.16283^{\mathrm{b}}$

(0.10553)

0.07516

$(0.10761)$

$0.23207^{\mathrm{b}}$

(0.12418)

$0.41539^{\mathrm{C}}$

(0.16173)

$0.92349^{\mathrm{C}}$

(0.18166)
$-0.09736$

(0.11388)

0.10029

$(0.09815)$ 
Table VI. Elasticity of Migration with Respect to Affinity for Appalachia ${ }^{a}$ Continued

a Numbers in parentheses are standard errors.

b Statistically significant at the ten percent level or beyond.

c Statistically significant at the one percent level or beyond

Table VII. Proportion of Variance Explained by the Model

$\underline{\text { State }}$

Alabama

Georgia

Kentucky

Maryland

Mississippi

New York

North Carolina

Ohio

Pennsylvania

South Carolina

Tennessee

Virginia

West Virginia

\section{Appalachian \\ Residents}

\subsection{3}

0.7953

0.6859

0.5524

0.7797

0.7465

0.7087

0.7110

0.7957

0.7548

0.7505

0.7027

0.7326
Non-Appalachian

Residents

0.7802

0.8154

0.6591

0.7557

0.8387

0.7506

0.8120

0.7858

0.8126

0.8077

0.7830

0.7969

The job opportunity variable works well, being statistically significant beyond the one percent level in every case. Again, however, we remind the reader that this variable may well be serving as a proxy for population size.

The results pertaining to the distancevariable tend to refute the assertion of some observers that distance is an unimportant consideration to Appalachian migrants. In 11 of 13 instances the observed negative relationship between migration and distance was statistically significant at or beyond the five percent level. Interestingly, the elasticity of migration of Appalachians with respect to distance was greater than unity in most of the Southern states, but was substantially less than one in such Northern Appalachian states as Pennsylvania, Ohio, and New York.

The results of the population density variable support, although quite weakly, the original contention that, ceteris paribus, Appalachians preferred less densely populated states. All the elasticities fall between -0.5 and -.45 , with only four of them statistically significant at the five percent level.

Finally, there is some evidence that Appalachians do have some preference for Appalachian areas, ceteris paribus. This preference, however, is not as intense as some writings migh suggest. In 6 of 13 instances, the affinity coefficient is not significantly greater than zero. In general, the Appalachian affinity factor appeared to be relatively strong in the Northern and border Appalachian states, but quite weak or non-existent in the Southern Appalachian region.

Does the migration behavior of Appalachians differ substantially from that of persons living in non-Appalachian areas nearby? In general, the answer 
is "no". Tha Appalachian out-migrants did seem to be somewhat more responsive, ceteris peribus, to income differentials in making location decisions, although this difference was not usually significant at the five percent level. 8 Also, as one would expect, the Appalachians had a greater tendency to remain in the Appalachian region than did the non-Appalachian migrants. With respect to the other variables, no substantial differences between the two groups was observed.

IV.

While the above results are enlightening, some unansweredquestions remain. First, we observed above that Appalachians did have some tendency to move, ceteris paribus, within the Appalachina region. Is the influence of regional affinity in migration unique with Appalachian residents? To test this, we applied ou $r$ model to migration from the five state Ozark region for the same period, excepting, of course, that we now defined regional affinity in terms of the Ozark geographic area. Interestingly, with the exception of migrants from the Illinois Ozark counties, the migration of persons living in the Ozarks are strongly influenced by an apparent affinity for the Ozark region. The coefficient as sociated with the Ozarkaffinity variable for migrants from the Ozark regions of Missouri, Arkansas, Kansas, and Oklahoma was greater than the Appalachian affinity coefficient for every Appalachian state except West Virginia. In short, Appalachians do have an affinity for their region, but they are not unique in this respect.

Has the observed tendency of Appalachan migrants to respond to economic considerations been a relatively recent development? We have investigated interstate mobility for various dates 1850 using a very similar model. ${ }^{9}$ The income, job opportunity, distance and population density variables are defined in the same manner as above, although the regional affinity variable used is somewhat different. Also, our historical work utilizes the state of birth-state of resident data from various censuses, providing a measure of "long-term" interstate mobility, rather than over a clearly defined span of time. While we did not obtain results for the Appalachian region as such beca e of data limitations, we did obtain estimates for out-migration from West Tirginia, the only all-Appalachian state (see Table VIII). The results show that West Virginian migrants have responded to economic considerations in making their movement decisions for a long time. They have become much more sensitive to income differentials, however, in the past half-century. Likewise, they have become somewhat less responsive to the number of jobs. More striking, perhaps, has been the substantial decline in the importance of population density. Sensitivity to the costs associated with distance appears to $b$ ve remained remarkably constant. It is particularly reassuring to nute that the results obtained with the historical model are quite similar to those obtained using our model with the 1955-1960 data.

A final question arises. Did Appalachian migrants really improve their relative economic status by moving? The above results would seem to imply an affirmative answer to that question. However, the large amount of intraAppalachian movement would seem to vitiate the positive effects of the responsiveness to income differentials observed under the ceteris paribus assumption. To test this as sertion, we estimated simple regressions using only per capita income as an independent variable (Table IX). The results clearly suggest that, mutatis mutandis, Appalachian migrants have not generally improved their economic status (as measured by per capita income) by their location decisions. The weighted average of the income coefficients for the income coefficients for the thirteen state regressions is not significantly dif- 
ferent from zero at even the ten percent level. Holding other factors equal, then, migrants have responded positively to income differentials. But in fact other things (e.g., distance, Appalachian affinity) have not been equal for all the states. Taking this into account, Appalachian migrants have not only failed to improve their relative economic status by moving, but they may have failed to improve their absolute status as well.

Table VIII. Migration of West Virginians, 1880-1960

\begin{tabular}{|c|c|c|c|c|c|}
\hline Variable & $\underline{1880}$ & $\underline{1900}$ & $\underline{1920}$ & 1960 & $1960 \mathrm{~A}^{\mathrm{a}}$ \\
\hline Income & .34 & .54 & .87 & $2.47^{\mathrm{b}}$ & $2.45^{\mathrm{b}}$ \\
\hline Job Opportunity & $1.60^{\mathrm{D}}$ & $1.41^{\mathrm{D}}$ & $1.34^{\mathrm{D}}$ & $1.20^{\mathrm{D}}$ & $.92^{\mathrm{b}}$ \\
\hline Population Density & $-1.02^{b}$ & $\begin{array}{l}-1.02^{2} \\
-.94^{b}\end{array}$ & $\begin{array}{l}-1.11 \\
-.90^{b}\end{array}$ & $-1.0 \mathrm{~L}$ & $\begin{array}{l}-1.01 \\
-.26\end{array}$ \\
\hline
\end{tabular}

a The estimates derived above.

b Statistically significant at the five percent level or beyond.

In order to compare Appalachians with other Americans, we estimated elasticities of migration with respect to per capita income for migrants from the nine New England and Mid-Atlantic states, as well as for six western states. Statistically significant positive elasticities were observed in nearly every instance, with the coefficients typically exceeding two. This is further evidence that the Appalachian migrant has actually lost ground relative to other Americans through migration.

\section{V.}

Our empirical investigation of Appalachian geographic labor mobility from 1955 to 1960 suggest that the Appalachian migrant fits fairly well the ecomist's conceptualization of the maximizing individual. These migrants, ceteris paribus, have responded positively to income and job opportunities in making location decisions. They havelikewise tended to be affected by costs associated with movement (as measured by distance) and have tended to prefer sparsely populated areas. They seem to have an affinity for Appalachia, although regional affinity is not a unique characteristic of Appalachians. Some historical results indicate that the responsiveness of Appalachian migrants to economic considerations has existed since at least 1880 .

Unfortunately, however, there is little evidence here to suggest that Appalachian migrants have improved their economic status by their movement decisions. This is not explained, however, by any relative lack of perception on the part of the Appalachian migrant. Rather, it may well be a product of the geographical environment of Appalachia itself. The pecuniary and non-pecuniary costs associated with movement to areas with high per capita incomes and more job opportunities are greater for Appalachians than for migrants in most other parts of the country. Finally, the notion that Appalachians have a distinct subsculture with substantially different behaviorial responses thanother American groups receives little support from this investigation. 
Table IX. Mobility and Economic Status --

Elasticity of Migration with Respect to Per Capita Income Alone ${ }^{a}$

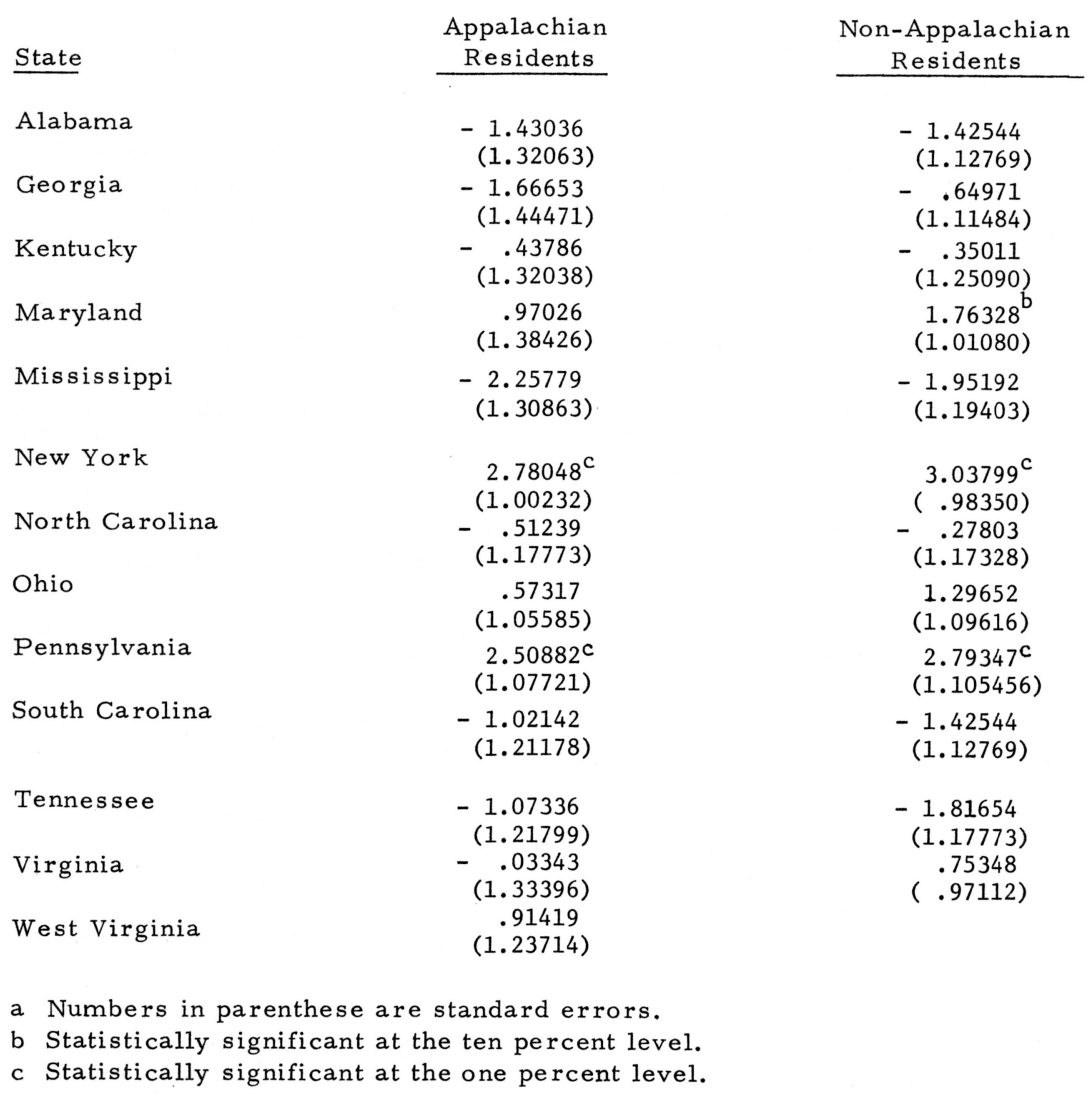




\section{FOOTNOTES}

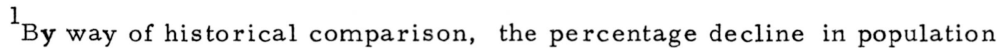
in the Appalachian portion of Kentucky from 1950 to 1960 was 14 percent, while the decline in Ireland from 1841 to 1851 (the period of the Great Potato Famine) was slightly less than 21 percent.

2 While much has been written on Appalachian migration, few studies have approached the subjectusing the tools of economic theory oreconometrics. One interesting such study is that of Mary Jean Bowman and W. W. Haynes, Resources and People in East Kentucky (Baltimore 1963).

${ }^{3}$ Jack E. Weller (Lexington 1965). In the authors' judgment, this is actually one of the better accounts of the Appalachian socio-cultural milieu.

4 In E. A. G. Robinson, editor, Backward Areas in Advanced Countries: Hoover was concurring with a stateme nt by Ralph R. Widner of the Appalachian Regional Commission, and on results of Ira Lowry suggesting distance is an unimportant factor in intercity migration. See Ralph R. Widner, Experiment in Appalachia," Pittsburgh Business Review, March 1967, p. 14; and Ira S. Lowry, Migration and Metropolitan Growth (San Francisco 1966).

${ }^{5}$ See specifically the U.S. Census of Population: 1960; Subject Reports, Mobility for States and State Economic Areas (Washington, D. C. 1963).

${ }^{6}$ See Lowell E. Gallaway and Richard K. Vedder, "Mobility Native Americans" Journal of Economic History, September 1971.

${ }^{7}$ It might seem that a better measure of relative income would be obtained by dividing the per capita income statistic for all the jthobservations by the income in the state of orgin (the ith state.) In as much as this involves dividing all the observations by a constant, the only effect that this would have is on the constant term, which is irrelevant in terms of testing our hypothesized mode1.

${ }^{8}$ The income coefficients, however, are generally slightly lower than those estimated for other states using different data and a slightly different model. Galloway and Vedder, op. cit.

${ }^{9}$ Ibid. 